\title{
INSIDE AND OUTSIDE THE TRANSLATION CLASSROOM
}

\author{
PaUlina Pietrzak \\ University of Lodz, Poland \\ paulina.pietrzak@uni.lodz.pl
}

\begin{abstract}
The article provides a glance at the continuing transformation in the profession of translators and its implications on translator training. The profile of the translator has never been unified but nowadays, following the pandemic situation in the year 2020 , the profession undergoes a significant shift as a result of the economic situation and the effects of the pandemic restrictions on the condition of the labour market. The widespread use of technology and new requirements involving distance learning call for rethinking the aims of translator training.

The primary purpose of the article is to signal the need for adapting translator training to foster better metacognitive skills that help translation students adapt to the evolving market. The article makes an attempt to look at the potential of distance translator training for introducing more professionalization into translator education. Moving outside the regular translation classroom to virtual training environments can in fact entail the learner transformation not only as regards technology immersion but also their autonomy.
\end{abstract}

Keywords: translator training, technology and teaching, translator education

\section{The impact of technology on translator training}

Translation industry is currently undergoing a significant transformation, encompassing workflow, workforce and workspace. The broadly-defined translating is a highly technologized and differentiated profession, which results in the changing profile of the translator. The changes that the profession has had to accommodate require a remarkable ability on the part of the translator to adapt to the constantly evolving translation market. Given that translator competences and qualifications differ depending on the profile of the translator's job, translator training must take into account not only learning objectives and institutional requirements but also the requirements of the market. 
Job requirements depend largely upon the economic situation and the overall condition of the labour market. The translation profession has been greatly affected by the pace of digital advancement and the overall technological development. Technology can indeed be a powerful weapon on the battlefield of the translation industry. Computer-assisted translation (CAT) technology offers great aid to translators as it simplifies and accelerates the process of translation. Nevertheless, it needs to be emphasized here that the use of technology must be well-integrated and comprehensive to ensure productive work and extend both translation and translation service provision in powerful ways.

The most effective use of technology encompasses using a variety of tools and selecting the one that is most suitable for the given task. Interestingly, despite the usefulness of CAT tools, translators still remain divided into users and nonusers of CAT technology. It needs to be acknowledged that "while the CAT tool is generally expected to aid and support the translation process, it may also offer resistance and restrain the process in several ways" (Bundgaard 2017: 126). There is a lot of technology-related anxiety in the translator's profession; it can stem from the fact that the profession is susceptible to automation and translators are increasingly concerned about their careers and the future of the very profession (Pietrzak and Kornacki 2020: 58).

Another type of technology-related anxiety involves the discomfort of translator-technology interaction. One aspect of this type of anxiety is called cognitive friction, that is an extraneous cognitive load usually caused by "unhelpful or distracting CAT tool features" (O'Brien et al. 2017: 147). While cognitive friction hinders the process of translation, there is also technological anxiety - a fear of computer assistance - that actually prevents the process of translation from happening (Pietrzak and Kornacki 2020: 61). The challenge remains for future research to investigate the attitudes towards technology after this period of the extended interaction with technology resulting from the pandemic situation.

It needs to be observed here that the pandemic, with its economic and sociocultural effects, has exerted a great impact on the translation industry. As a result of the increasing presence and huge reliance on technology, new types of work profiles and work systems emerge and affect the translation business. Translation students need to be prepared for the dynamic changes that occur nowadays as the current market challenges are particularly difficult to deal with for translators whose skills are out of step with demand. Therefore, the question arises about the implications of these changes for translator training.

\section{Identifying the needs}

It has always been difficult to define translator competences and qualifications required for the profession. Models of translator competence that explore the 
concept of translator competence (e.g. Lörscher 1991; Göpferich 2009; Gouadec 2007; Kelly 2005, 2008; Kiraly 1995, 2000, 2015, 2016; PACTE 2003; Pym 2003; EMT 2017) identify the necessary components of translator competence that the ideal translator should possess. It is, however, hard to define the set of skills that would be universal for all translators since there is a wide scope of translation services provided.

A diversity of professional translation activities makes any attempt at defining the translator's job qualifications particularly challenging. Moreover, the growth of innovation in the translation industry has affected the profile of the translator to such an extent that it is even harder to identify the specific scope of work and duties universal for every translator. Nonetheless, the necessary skills need to be identified and taken into account in translation curricula. That is why, translation competence is the concept that requires particular attention now. In a holistic approach to translator education, it is emphasized that translator competence involves both "the acquisition of knowledge of translation theory (episteme) and the development of practical wisdom (phronesis)" (Haro-Soler and Kiraly 2019: 257). This is the latter that needs to be reconsidered by translation educators in an attempt to identify not only the necessary skills but also the ways in which these skills can be acquired.

Any changes in the translator's profile must be taken into account in the organisation of translation study programmes and curricula design. New market demands and students' needs require rethinking the aims of training and adjusting new approaches. Over the last two decades there has been a considerable increase in the study of teaching translation and translation-related skills. New approaches emerged to stress the equal importance of both linguistic and non-linguistic aspects of translator education. A conventional transmissionist practice has a long history in translator education, but nowadays translator training is no longer a teacher and product-centered practice. Teaching practices evolve and aim to favour student agency, autonomy and empowerment (Kiraly 1995, 2016, 2019; González Davies 2004, Klimkowski 2015). Learner and process-centered approaches entail collaborative, situated and competence-based training.

Currently, new translator training environments created by the global implementation of distance learning moved training outside the regular translation classroom. Despite the obvious difficulties and all the cons of distance learning, this transition to an online learning environment can actually contribute to more student-oriented training, provided that a good setup is ensured. Although the year 2020 has brought sudden and rather unwelcome changes to translation education, the advantage of distance learning is that it requires students to become more autonomous and handle additional responsibility for their own process of leaning, which engages them more than classroom-based instruction. 


\section{New translator training environments}

The flexibility of distance translator training can indeed contribute to collaborative and process-centered translator training. Such student-oriented approaches can be successfully implemented also in distance learning to cater for the pressing need to prepare students to not only translate but rather, more holistically, provide translation services. True collaboration in translator training does not mean being together or "having learners do translations individually in the company of peers. It means sharing responsibility for empowering the entire group as emergent professionals" (Kiraly 2000: 67).

The whole process of translator training is a collaborative knowledge construction, which requires situating, ie. near-authentic work settings and tasks that are as close to professional translation reality as possible (Kiraly 2016: 12). Klimkowski adds that, "an effective situating of T\&I education calls for extracurricular educational initiatives; not only to complement the formal T\&I curriculum, but also to expand the standard way of thinking about, planning and implementing T\&I educational holistic solutions" (2015: 151). Outside of the translation classroom, new translator training environments resemble the authentic circumstances and methods of work typical of professional translator workplace. Similar to field experiences, distance translator training requires collaboration in a joint effort to create best environment possible for translation students to acquire the necessary skills.

Given that translators often work with computer-assisted software and collaborate by means of various types of technological tools, distance training can in fact contribute to the professional development of the translator. It goes in accordance with the assumptions of experiential learning (Kolb 1984) and the approaches used in the professionalisation of the translator, such as design approach or project-based collaboration. Translation projects (cf. González Davies 2004, Kiraly 2019) involve methods of work typical of professional translator workspace where teacher, students, practitioners and field specialists collaborate outside the translation classroom.

A project-based approach that can be easily adapted to new circumstances and challenges of distance learning is PATT (Professional Approach to Translator Training), postulated by Lobo et al. (2007: 521). The main theoretical assumption of PATT (ibid.) are as follows:

- To familiarize students with the methods of work typical of translation agencies by recreating the production line of the professional workplace. Students carry out the tasks of information scientists, terminologists, revisers, editors and typesetters. They even take on the responsibility of project supervisor, a role that is not normally included in teaching contexts but which is more and more important in the workplace.

- To develop teleworking in teams, self-instruction and interdisciplinarity. 
- To provide a work setting with the tools needed by teachers and researchers to incorporate ICT [information and communication technology] in the classroom and reproduce the environment of the professional work context. Our approach allows us to obtain first hand information on the impact of ICT on university teaching.

- To promote coordination between subject matter areas in the university teaching of translation.

Despite all its drawbacks, distance translator training can in fact serve as a way of reproducing the environment of the professional work context and, thus, situating the translation students' work. As it can fully recreate the production line of the professional workspace, it has the potential of familiarizing students with teleworking in teams and taking various roles in a project. At the same time, distance translator training involves the extensive use of metacognitive strategies, such as self-regulation, self-assessment or self-directed learning. Such a real-life practice of metacognitive skills can actually lead to the professional development of translation students also in the psychophysiological dimension.

\section{Focus on metacognition in translator training}

Metacognition is a crucial component of any successful learning process (eg. Baker, 1989; Garner \& Alexander, 1989; Garner 1990). While cognitive skills refer to learning, metacognitive skills refer to managing learning. Metacognition involves using "higher-level knowledge and strategies to regulate lower performance" (Schraw, Wise and Roos 2000: 223). Metacognitive approach to education focuses on the self of the translation student with the aim of helping students to adapt their learning to new contexts and tasks (Bransford, Brown, \& Cocking 2000: 12-18).

Metacognitive training focuses on such self-regulatory strategies as planning, monitoring, reflecting (Baker 1994) but also executive processes such as predicting, checking, revising, evaluating, coordinating and controlling (Brown 1978). Metacognitive translator training can be defined as a support in learning through activating translation students' personal resources such as self-regulation (cf. Pietrzak 2018) and self-reflection (cf. Pietrzak 2019a, Pietrzak 2019b). Developing such skills help both trainers and trainees move towards more autonomous translator training. Learner autonomy appears fundamental for further development and specialisation, which consequently enables translation students to become self-directed life-long learners.

Kiraly (2000: 49) observes that, "if we see translator competence as a creative, largely intuitive, socially-constructed, and multi-faceted complex of skills and abilities, then the primary goals of translator education will include raising students' awareness of the factors involved in translation, helping them develop their own translator's self-concept, and assisting in the collaborative 
construction of individually tailored tools that will allow every student to function within the language mediation community upon graduation". Klimkowska (2013: 47) notes that Kiraly's concept of the translator focuses on the psychosocial subcompetence, thanks to which the translator has such tools as: self-awareness, self-control, self-reflection, ability and readiness for introspection or ability of efficient social functioning.

In the light of the challenges facing future generations of translators, rethinking the aims of translator training is inevitable. Given that the future translator must be a self-regulated life-long learner ready to adapt to new trends, more attention needs to be devoted to the holistic translator education. Changes in technology and social life compel translator trainers to focus on metacognitive skills and the broadly-defined psychological self of the trainee translator. What is required is a holistic approach to translation curriculum that would "cater for the overall, life-long human growth and functioning - as individuals, members of groups, teams, communities and societies" (Klimkowski 2015: 47). Metacognitive translator training seems to be best in times of uncertainty as it involves developing translator competence with a careful consideration towards the learner's awareness of the metacognitive aspects of becoming a translator in the uncertain and indeterminate translation business.

\section{Aims and scope of the special issue}

This special issue offers a collection of original articles on translator training, responding to the increased interest in collaborative translator education, evidenced by the amount of research devoted to this area of translation studies. The primary aim behind this collection is to contribute to the current pedagogical debate with the main research focus on not only linguistic and cultural issues relevant to translator education but also collaborative educational policies intended to improve translator training.

The issue is divided into two sections: Part I which explores collaborative approaches and methodological trends towards authentic learning environments and Part II which is devoted to more specific linguistic issues in translator training.

Part I includes three articles. In the first article, Yvonne Tsai (National Taiwan University, Taiwan) investigates the effectiveness of collaborative translation teaching methods. The author explores two types of practice, face-toface and virtual collaboration, in an attempt to establish a collaborative translation framework offering the core criteria of collaboration, its effectiveness and efficiency.

Following in this vein, the second article, by Gökçen Hastürkoğlu (Atılım University, Turkey) and Özge Bayraktar Özer (Atılım University, Turkey) is an empirical study of the efficacy of collaborative translator training with particular attention to the undergraduate level. The researchers make an attempt to validate 
their collaborative learning model and show the efficacy of their method in technical translation courses.

In the third article, Olga Mastela (Jagiellonian University, Poland) presents an authentic collaborative project devoted to transcreating legends and folk tales. The author demonstrates her out-of-classroom approach to translator training and stresses the need for introducing more activities enhancing translation trainees' creative thinking.

The fourth article, by Baaziz Termina (Mohamed V University Rabat, Morocco) explores the implications of cognitive linguistics for translation pedagogy. The author illustrates translation problems that are conceptual in nature and discusses them within the framework of cognitive linguistic models.

In the fifth article, by Lora Tamošiūnienè (Mykolas Romeris University, Lithuania), the focus is laid on the translation of nature scenes and objects. The article offers a comparison of translation strategies in English and Lithuanian translations of the Korean novel rich in nature references and nature terminology.

The last article, by Marcin Lewandowski (Adam Mickiewicz University, Poland) touches upon the problematic issues of cohesion in Polish-English translation. The author discusses the ways of maintaining cohesive links in the translation process and provides some implications for translator training.

The contributions to this collection address only selected issues relevant to translator training, but all the pieces illustrate the fact that translation education combines interlinguistic and intercultural issues with interpersonal and metacognitive aspects that are so crucial for effective collaboration inside and outside the translation classroom.

\section{References}

Baker, Linda. 1989. Metacognition, comprehension monitoring, and the adult reader. Educational Psychology Review, 1, 3-38. https://doi.org/10.1007/BF01326548

Baker, Linda. 1994. Fostering metacognitive development. In Hayne W. Reese (eds.), Advances in Child Development and Behavior, vol. 25, 201-239. San Diego: Academic Press. https://doi.org/10.1016/S0065-2407(08)60053-1

Bransford, John D., Brown Ann L., and Cocking Rodney R. 2000. How people learn: Brain, mind, experience, and school. Washington, D.C.: National Academy Press.

Brown, Ann L. 1978. Knowing when, where and how to remember: A problem of metacognition. In Robert Glaser (ed.), Advances in instructional psychology, vol. 1, 77-165. Hillsdale, NJ: Lawrence Erlbaum.

Bundgaard, Kristine. 2017. Translator Attitudes Towards Translator-Computer Interaction Findings from a Workplace Study. HERMES-Journal of Language and Communication in Business, 125-144. https://doi.org/10.7146/hjlcb.v0i56.97228

EMT Expert Group (2009) Competences for professional translators, experts in multilingual and multimedia communication, Brussels, European Commission.

EMT Expert Group, 2017. Competence Framework 2017. [Online] Available at: https://ec.europa.eu/info/sites/info/files/emt_competence_fwk_2017_en_web.pdf (Accessed 3 January 2020) 
Lörscher, Wolfgang. 1991. Translation performance, translation process, and translation strategies: A Psycholinguistic investigation. Tübingen: Gunter Narr.

Garner, Ruth and Alexander, Patricia A. 1989. Metacognition: Answered and unanswered questions. Educational Psychologist, 24, 143-158. https://doi.org/10.1207/s15326985ep2402_2

Garner, Ruth. 1990. When children and adults do not use learning strategies: Toward a theory of settings. Review of Educational Research, 60, 517-529.

González Davies, Maria. 2004. Multiple Voices in the Translation Classroom. Amsterdam: John Benjamins. https://doi.org/10.1075/btl.54

Göpferich, Susanne. 2009. Towards a Model of Translation Competence and its Acquisition: The Longitudinal Study Transcomp. In: Göpferich, Susanne. Jakobsen, Arne. L. and Mees, Ingrid. M. (eds.), Behind the Mind. Methods, Models and Results in Translation Process Research. 1137. Copenhagen: Samfundslitteratur Press.

Gouadec, Daniel. 2007. Translation as a Profession, Amsterdam/Philadelphia: John Benjamins. https://doi.org/10.1075/btl.73

Haro-Soler, Maria and Kiraly, Don. 2019. Exploring Self-efficacy Beliefs in Symbiotic Collaboration with Students: an Action Research Project. The Interpreter and Translator Trainer, 13(3). 255-270. https://doi.org/10.1080/1750399X.2019.1656405

Kelly, Dorothy. 2005. A handbook for translator trainers; A guide to reflective practice, London/New York: Routledge.

Kiraly, Don. 1995. Pathways to Translation: Pedagogy and Process. Kent: Kent State University Press.

Kiraly, Don. 2000. A Social Constructivist Approach to Translator Education. Empowerment from Theory to Practice. Manchester, St. Jerome.

Kiraly, Don. 2015. Occasioning Translator Competence: Moving beyond Social Constructivism towards a Postmodern Alternative to Instructionism, Translation and Interpreting Studies, 10(1) (Special Issue), 8-32. https://doi.org/10.1075/tis.10.1.02kir

Kiraly, Don. 2016. Authentic Project Work and Pedagogical Epistemologies: A Question of Competing or Complementary Worldviews? In Donald C. Kiraly et al. (eds.), Towards Authentic Experiential Learning in Translator Education. 53-66. Mainz, Mainz University Press. https://doi.org/10.14220/9783737004954.53

Kiraly, Don. 2019. A Human Pyramid (castell): A Metaphor for Authentic Project Work, Keynote Speech at APTIS Conference 2019 (Association of Programmes in Translation and Interpreting Studies, UK and Ireland) 23-24 November, Presentation, DOI: 10.13140/RG.2.2.28589.03047

Klimkowska, Katarzyna. 2013. Orientacja na sukces zawodowy studentów kończących studia translatorskie. Lublin: Wydawnictwo Uniwersytetu Marii Curie-Skłodowskiej.

Klimkowski, Konrad. (2015). Towards a shared curriculum in translator and interpreter education. Wrocław/Washington, D.C.: WSF, PAN and International Communicology Institute.

O'Brien, Sharon, Ehrensberger-Dow, Maureen, Hasler, Marcel and Connolly, Megan. 2017. Irritating CAT Tool Features that Matter to Translators. HERMES-Journal of Language and Communication in Business, 56, 145-162. https://doi.org/10.7146/hjlcb.v0i56.97229

PACTE. 2003. Building a Translation Competence Model. In Fabio Alves (ed.), Triangulating Translation: Perspectives in process oriented research. 43-66. Amsterdam/Philadelphia: Benjamins. https://doi.org/10.1075/btl.45.06pac

Pietrzak, Paulina. 2018. The effects of students' self-regulation on translation quality. Babel: International Journal of Translation ,64(5/6). 819-839. https://doi.org/10.1075/babel.00064.pie

Pietrzak, Paulina. 2019a. Scaffolding student self-reflection in translator training. Translation and Interpreting Studies, 14(3). 416-436. DOI: doi.org/10.1075/tis.18029.pie

Pietrzak, Paulina. 2019b. An integrated approach to assessment in translator training: the value of self-reflection. In Barbara Lewandowska-Tomaszczyk (ed.), Contacts and Contrasts in 
Educational Contexts and Translation. 105-115. Berlin Heidelberg: Springer. https://doi.org/10.1007/978-3-030-04978-2 7

Pietrzak, Paulina and Kornacki, Michał. 2020. Using CAT Tools in Freelance Translation: Insights from a Case Study, New York: Routledge. https://doi.org/10.4324/9781003125761

Pym, Anthony. 2003. Redefining Translation Competence in an Electronic Age. In Defence of a Minimalist Approach. Meta: Translators' Journal, 48(4), 481-497. https://doi.org/10.7202/008533ar

Schraw, Gregory; Wise, Steven L.; and Roos, Linda L. 2000. Metacognition and Computer-Based Testing. In Gregory Schraw and James C. Impara (eds.),Issues in the Measurement of Metacognition. Lincoln, NE: Buros Institute of Mental Measurements. 